\title{
Structural Engineering and Mechanical Properties of (Ti-V-Zr-Nb-Hf-Ta)N Coatings Obtained at Different Pressures
}

\author{
O.V. Sobol'1,*, A.A. Andreev², H.O. Postelnyk ${ }^{1}$, A.A. Meylekhov'1, Yu.Ye. Sagaidashnikov'1, \\ V.A. Stolbovoy ${ }^{2}$, N.S. Yevtushenko ${ }^{1}$, T.O. Syrenko ${ }^{3}$, Zh.V. Kraievska ${ }^{1}$, A.V. Zvyagolskiy ${ }^{1}$ \\ ${ }^{1}$ National Technical University "Kharkiv Polytechnic Institute», 2, Kyrpychov St., 61002 Kharkiv, Ukraine, \\ ${ }^{2}$ National Science Center Kharkov Institute of Physics and Technology, 1, Akademicheskaya St., 61108 Kharkiv, \\ Ukraine \\ ${ }^{3}$ Kharkiv Machine-Building College, 79, Plekanivska St., 61068 Kharkiv, Ukraine
}

(Received 11 January 2019; revised manuscript received 10 June 2019; published online 25 June 2019)

\begin{abstract}
Effect of pressure of the reaction gas on the texture, structural stress state and mechanical properties (hardness and resistance to abrasive wear) in vacuum-arc coatings based on Ti-V-Zr-Nb-Hf-Ta nitrides of high entropy alloys were investigated in this work. At a bias potential of $-200 \mathrm{~V}$, an increase in nitrogen pressure during deposition from $2.5 \cdot 10^{-4}$ to $4.5 \cdot 10^{-3}$ Torr leads to an increase in the content of nitrogen atoms in the coating, and the formation of a bittexture state [111] + [311] is established. The formation of a biaxial texture occurs due to the presence in alloys of atoms with very different masses (Ti, V and $\mathrm{Hf}, \mathrm{Ta}$ ). The use of a multi-element composition in a single-phase state with a simple cubic lattice allows to achieve high values of microstrain (up to $1.4 \%$ ) with a low deposition pressure. It is determined that the increase of nitrogen pressure during deposition leads to an increase in macrostresses. The highest hardness of $53 \mathrm{GPa}$ is achieved in coatings obtained at a pressure of $2 \cdot 10^{-3}$ Torr. It has been established that coatings with high resistance to abrasive wear are found to be: crystallite grain size 12-25 nm, absent of texture (or a low level of texture perfection), and also rather high microstrain in crystallites.
\end{abstract}

Keywords: High entropy alloys, Nitrogen pressure, Coatings, Texture, Substructural characteristics, Bias potential, Hardness, Abrasive wear.

DOI: $10.21272 /$ jnep.11(3).03013

PACS numbers: 64.75.St, 81.07.Bc, 62.25.-g, 61.05.cp, 61.82.Rx

\section{INTRODUCTION}

Working surface determines the basic functional properties of the material $[1,2]$. Therefore, various methods of surface modification are being developed in order to achieve high hardness, low friction coefficient, high resistance to oxidation and wear [3, 4]. The most effective method of achieving high functional properties is ion-plasma deposition of special coatings [5] or the creation of structural nanocrystalline states with a strengthened boundary (due to doping with special elements [6]).

Currently, the two most promising types of coatings are multilayer nanostructured composites [7] and multi-element coatings (4 or more elements) $[8,9]$. The use of such materials allows to achieve a superhard state in multiperiod systems with a layer thickness of less than $10 \mathrm{~nm}$ [10] or a corresponding crystallite size in multi-element systems [11].

Among multi-element coatings, the greatest effect of increasing the functional properties was achieved for nitride high-entropy alloys (NHEA) [12].

The main distinctive feature of high-entropy alloys (HEA) is the presence of dissimilar atoms in the lattice of the solid solution [13]. Due to the different electronic structure, size, and thermodynamic properties, atoms significantly distort the crystal lattice of the substitution solid solution [14]. This contributes to significant solid solution hardening [15]. In addition, the reduced free energy of HEA ensures the stability of the solid solution during the subsequent heat treatment, which was confirmed by various authors [16].
HEA thus formed may have increased strength combined with good oxidation resistance and corrosion. To achieve high entropy, the alloy should, as a rule, consist of five or more basic elements with an atomic concentration of each between 5 and $35 \%$.

In this work, transition metals with high free energy gain in the formation of nitrides were selected as components of the high-entropy alloys. These are Ti, $\mathrm{Nb}$ and Ta with an atomic radius close to $0.145 \mathrm{~nm}, \mathrm{Zr}$ and $\mathrm{Hf}$ with an atomic radius close to $0.16 \mathrm{~nm}$ and $\mathrm{V}$ with an atomic radius of $0.132 \mathrm{~nm}$. At the same time, $(\mathrm{Nb}$, Ta and $\mathrm{V}$ ) have a bcc lattice at room temperature and form a continuous series of solid solutions between themselves. Hf, $\mathrm{Zr}$ and $\mathrm{Ti}$ also form continuous solid solutions with each other. They have a hcp crystal lattice at room temperature, but have a bcc lattice at high temperatures. At the same time, $\mathrm{Hf}, \mathrm{Zr}, \mathrm{Nb}$ and $\mathrm{V}$ are $\beta$-stabilizers for titanium.

In such a combination, it is possible to create stable nitrides based on multi-element HEA [17]. In such complex multi-element materials one can expect a decisive influence on the structure and properties of the coating on the magnitude of the pressure of the reactive nitrogen atmosphere $\left(P_{N}\right)$ and the bias potential $\left(U_{b}\right)$ during deposition.

The purpose of this work was to analyze the influence of $P_{N}$ on the structural-stress state and mechanical properties (hardness and resistance to abrasive wear) in coatings of NHEA. 


\section{SAMPLES AND METHODS OF EXPERIMENTS}

The cathodes for vacuum-arc evaporation were produced from HEA of the Ti-V-Zr-Nb-Hf-Ta system obtained by the method of vacuum-arc melting in an atmosphere of high-purity argon.

The deposition of coatings was carried out in a modernized installation "Bulat-6" [18]. Polished plates of $12 \mathrm{X} 18 \mathrm{H} 9 \mathrm{~T}$ stainless steel and copper foil of $0.2 \mathrm{~mm}$ thick were used as the substrates. The coatings were deposited by applying a constant negative potential $U_{b}=-200 \mathrm{~V}$ to the substrate, an evaporator arc current of $90 \mathrm{~A}$, a residual gas pressure of $2.5 \cdot 10^{-5}$ Torr. The nitrogen pressure in the deposition process was $2.5 \cdot 10^{-4}-4.5 \cdot 10^{-3}$ Torr. The coating deposition rate was about $1.5 \mathrm{~nm} / \mathrm{s}$.

Deposition parameters, as well as hardness $(H)$ and the ratio of the hardness to the reduced modulus of elasticity $\left(H / E_{r}\right)$, are presented in Table 1.

Table 1 - Deposition parameters and indentation results

\begin{tabular}{|c|c|c|c|c|c|c|}
\hline $\begin{array}{c}\text { Series } \\
\text { No }\end{array}$ & $I_{a}, \mathrm{~A}$ & $U_{b}, \mathrm{~V}$ & $P_{N}$, Torr & $H, \mathrm{GPa}$ & $H / E_{r}$ & $E_{r}, \mathrm{GPa}$ \\
\hline 1 & 90 & -200 & $2.5 \cdot 10^{-4}$ & 44 & 0.141 & 311 \\
\hline 2 & 90 & -200 & $5 \cdot 10^{-4}$ & 43.5 & 0.139 & 310 \\
\hline 3 & 90 & -200 & $7 \cdot 10^{-4}$ & 52 & 0.160 & 324 \\
\hline 4 & 95 & -200 & $2 \cdot 10^{-3}$ & 54 & 0.165 & 325 \\
\hline 5 & 90 & -200 & $4.5 \cdot 10^{-3}$ & 48 & 0.152 & 316 \\
\hline
\end{tabular}

The study of the structural-stressed state was carried out on a DRON-3M X-ray diffractometer in $\mathrm{Cu}-\mathrm{K}_{\alpha}$ radiation using a graphite monochromator. The study of the phase composition and texture of the coating was carried out using traditional X-ray diffraction techniques by analyzing the position, intensity and shape of the diffraction reflex profiles [7]. The degree of texturing was determined by the width of the rocking curve during the $\theta$ scan [5].

The elemental composition of the coating areas was determined by the micro X-ray spectral method on the «CAMEBAX microbeam» electron probe microanalyzer. The concentration of components was determined as the average of 8-10 local measurements at different coating areas for each sample.

Microindentation was carried out on the installation "Micron-gamma" at a load of up to $F=0.5 \mathrm{~N}$ using a diamond Berkovich pyramid with a sharpening angle of $65^{\circ}$, with automatically performed loading and unloading for 30 seconds.

The study of resistance to abrasive wear was carried out on the device "CSM Instruments CALOWEAR" designed to carry out tests for wear coatings using the method of spherical excavation using diamond abrasive "Calowear Superfine $<0.2 \mu \mathrm{m}$ ". The "CSM Instrument Calowear" instrument (the general view is shown in Fig. 1) allows determining the wear rate - the value is inversely proportional to the wear coefficient. The principle of operation is the formation of a spherical recess on the test sample. For this, the ball (coated with diamond abrasive) is rotated on the surface of the sample by means of the motor shaft. Rotating, the ball produces a spherical notch wear on the surface of the sample. For linear wear, the wear rate $K$ is defined as:

$$
K=\left(\pi d^{4}\right) /\left(64 R \cdot L \cdot F_{N}\right)
$$

where $L$ is the sliding distance; $F_{N}$ is the normal load on the sample; $d$ is the diameter of the notch; $R$ is the radius of the sphere [19]. The size of the resulting groove is determined using an optical microscope.

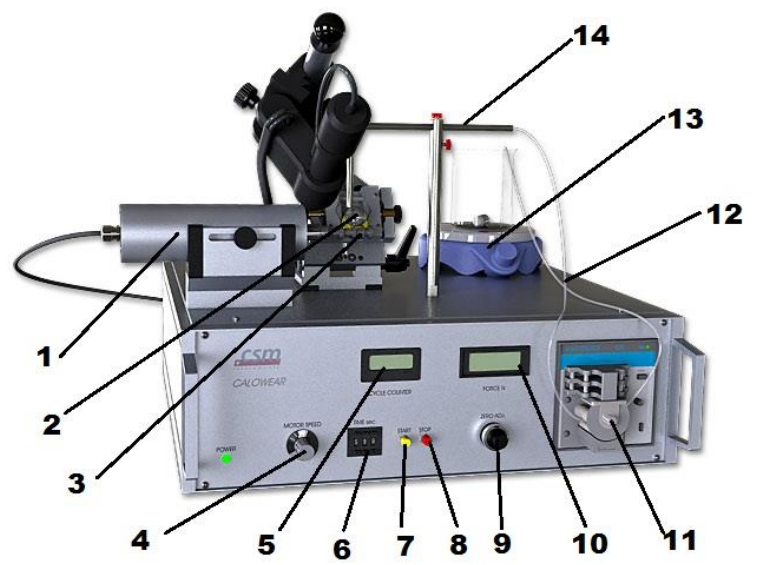

Fig. 1 - General view of the device CALOWEAR: 1 - engine; 2 - ball; 3 - motor shaft; 4 - shaft speed controller; 5 - cycle counter; 6 - selector to set the time; 7 -START button; $8-$ STOP button; 9 - "Zero" setting knob; 10 - indicator of the value of normal force; 11 - pump; 12 - hose; 13 - set for mixing the suspension; 14 - metal guide for hoses

\section{RESULTS AND DISCUSSION}

The study of the surface morphology of nitrides of HEA showed that the surface is structured into cells with a size of several micrometers, which is typical of other highly hard vacuum-arc coatings (TiN, MoN, ZrN, etc.) [18]. On the outer surfaces of the coatings a droplet phase is detected. With increasing nitrogen pressure in the working chamber during the deposition process, the number and size of the droplet phase decreases. The coating structure is columnar (Fig. 2). The columnar structure is most pronounced for coatings produced at low pressure (Fig. 2a).

As can be seen from Tables 1 and 2, the pressure of nitrogen during deposition affects its content in coatings to the greatest extent. However, even the highest content of 43.41 at. \% is also less than stoichiometric for mononitride (50 at. \%). This reduced nitrogen content is apparently related to the processes stimulated by ion bombardment at high $U_{b}=-200 \mathrm{~V}$. In this case, secondary sputtering (in the near-surface region of growth of the coating) leads to selective depletion of nitrogen atoms (as the lightest) [12]. With metal atoms, with increasing $P_{N}$, the content of Ti atoms (having a high energy of formation of nitride) increases. To the greatest extent, with increasing $P_{N}$, the content of Hf atoms decreases (by $22 \%$ ). The reason for this effect is the large scattering of heavy atoms in the interelectrode gap during deposition [12].

Fig. 3 shows the characteristic energy dispersive spectrum of the elemental composition of the coating (series $4, P=2 \cdot 10^{-3}$ Torr). 


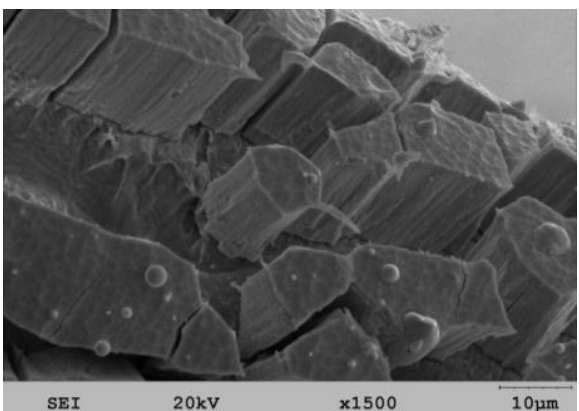

a

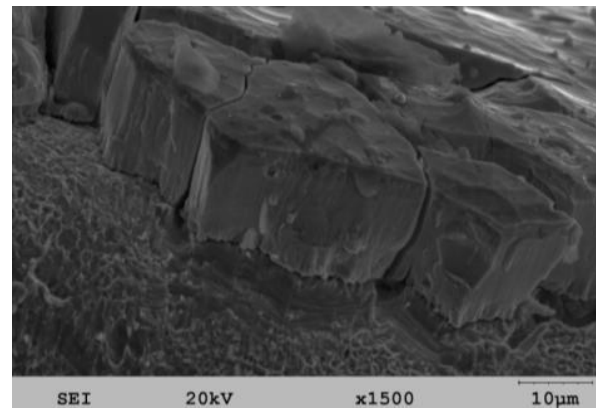

$\mathrm{b}$

Fig. 2 - Morphology of the coatings on the copper substrate: $\mathrm{a}-$ series $2, \mathrm{~b}-$ series 4

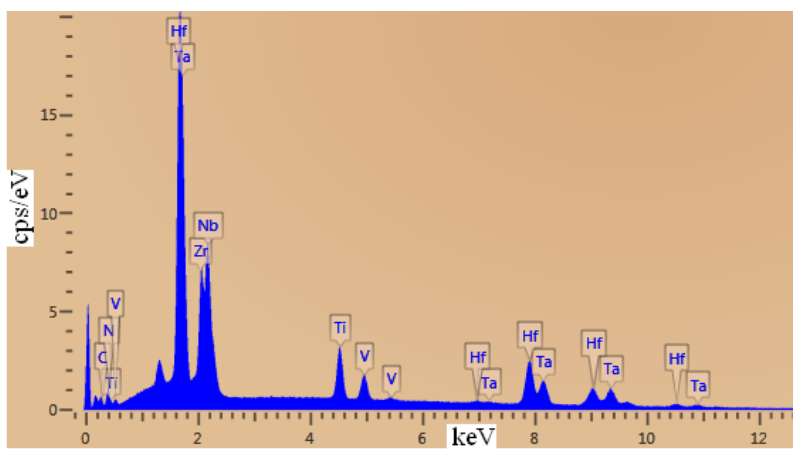

Fig. 3 - Energy dispersive spectrum of the elemental composition of the coating (series $4, P=2 \cdot 10^{-3}$ Torr)

It is seen that all the elements of the original target are present in the coatings. Also, a peak from the nitrogen component is detected in the spectrum. Table 2 shows the resulting data on the study of the elemental composition for 3 series of coatings.

Table 2 - The content of elements in the coatings according to the energy dispersive analysis

\begin{tabular}{|c|c|c|c|c|c|c|c|}
\hline series & \multicolumn{7}{|c|}{ Element, at. \% } \\
\cline { 2 - 8 } No & Ti & V & Zr & Nb & Hf & Ta & N \\
\hline 1 & 7.40 & 3.59 & 13.81 & 13.10 & 15.90 & 8.15 & 38.05 \\
\hline 3 & 7.59 & 3.26 & 13.25 & 13.07 & 13.49 & 8.07 & 41.17 \\
\hline 4 & 7.66 & 2.98 & 12.60 & 12.91 & 13.02 & 7.42 & 43.41 \\
\hline
\end{tabular}

As can be seen from Fig. 4, a single-phase state is formed on the basis of an fcc crystal lattice in the entire range of pressures used. For nitride, the structural type of this lattice is $\mathrm{NaCl}$. As can be seen from Fig. 4, for the nitride coating obtained at $U_{b}=-200 \mathrm{~V}$ and the smallest $P=2.5 \cdot 10^{-4}$ Torr (Fig. 4, spectrum 1), [311] texture formation occurs.
The formation of such a texture in fcc materials is often due to the high resistance of such a structural state to radiation defect formation [7]. This texture is maintained up to a comparatively high pressure $\mathrm{P}=2 \cdot 10^{-3}$ Torr (Fig. 4 , spectrum 4 ). At a higher pressure, a bit-texture state is formed with the main growth texture [111] (Fig. 4, spectrum 5). However, the degree of perfection of such a texture is small. This can be associated with the misorientation effect of atoms of six-element nitride components of different sizes in the lattice sites.

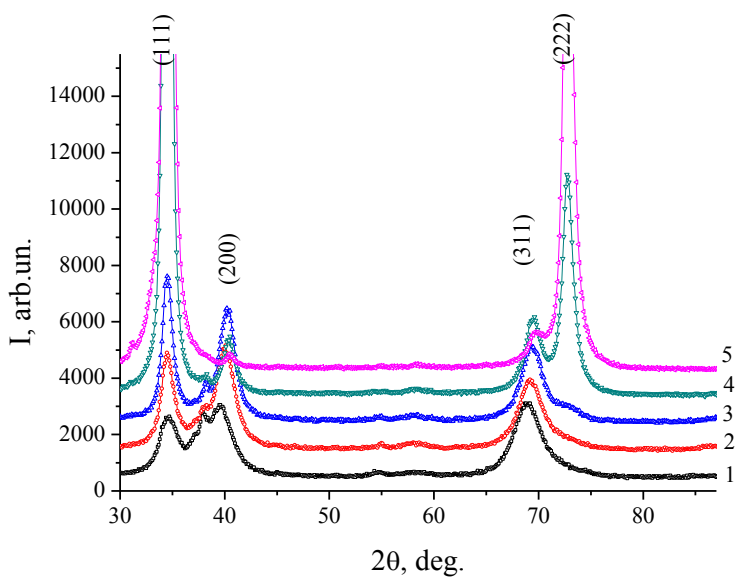

Fig. 4 - XRD-spectra of nitride coatings obtained at different pressures of the nitrogen atmosphere (the number of the spectrum corresponds to the number of the series in Table 1)

The appearance of a plane of preferred orientation of crystallites with the [100] axis of the texture at low pressure of the nitrogen atmosphere (curves 1-3 in Fig. 4) indicates an increase in the mobility [5] of the deposited particles as a result of a relatively low energy loss during collisions in the interelectrode gap.

As an intermediate conclusion, it can be noted that with an excess of nitrogen (at the highest pressure of $(2-4) \cdot 10^{-3}$ Torr), a [111] texture is formed. One of the main factors for the formation of this type of texture is the minimization of the strain energy of the system [7].

A comparison of the substructural characteristics (measured by the width of diffraction reflections at different angles) showed that with increasing pressure an increase in the average crystallite size occurs (see Fig. 5, dependence 1). This is determined by the fact that at low pressure of the nitrogen atmosphere, highenergy particles reach the growth surface with virtually no energy loss. In this case, a defective structure with a large number of crystallization centers is formed on the surface. This effect is most pronounced at pressures of (2.5-7) $10^{-4}$ Torr.

The change in the microstrain of crystallites with increasing pressure has a non-monotonic character (Fig. 5, dependence 2). At low pressures, microdeformation grows to $1.4 \%$. The reason for this is intense ion bombardment (which occurs at low pressure with virtually no energy loss by accelerated particles). At pressures greater than $7 \cdot 10^{-4}$ Torr, there occurs a decrease in the microstrain of crystallites. The reason for this effect is more equilibrium growth processes and a greater amount of relaxation due to an increase in the grain size.

The analysis of the stress-strain state was carried 
out by the method of multiple oblique surveys (" $a$ $\sin ^{2} \Psi$ '-method). The negative angle of inclination (" $a$ $\sin ^{2} \Psi$ '-graphs (Fig. 6)) occurs, that increases pressure of the nitrogen atmosphere. This is due to the development of greater compression macrostraction in the coating. A characteristic feature of the obtained " $a$ $\sin ^{2} \Psi$ '-graphs is their intersection almost at one point $\sin ^{2} \Psi \approx 0.4$. In the case of a cubic lattice, this intersection corresponds to a Poisson coefficient $(\mu)$ close to $0.25\left(\sin ^{2} \Psi_{0}=2 \mu /(1+\mu)\right)$.

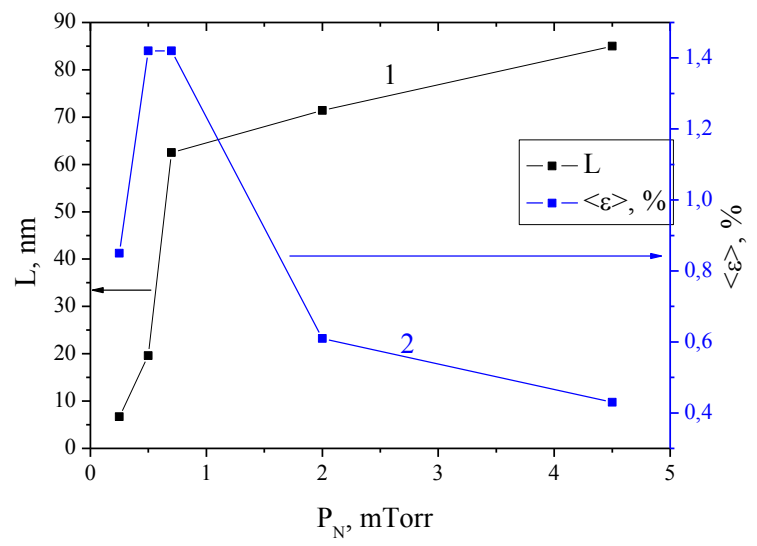

Fig. 5 - Dependence of the size of crystallite grains (1) and microstrain (2) on the pressure of the nitrogen atmosphere during the coating deposition

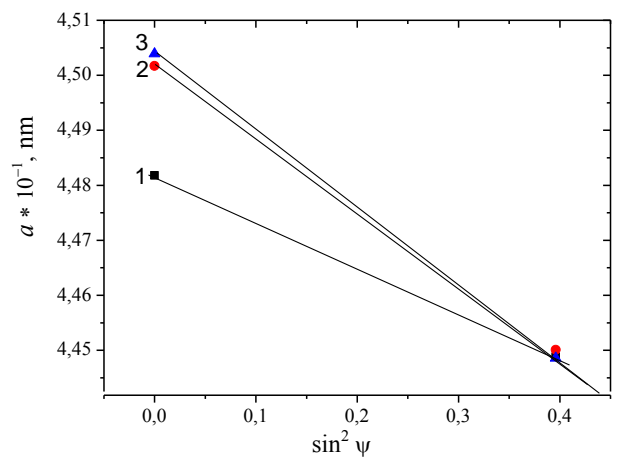

Fig. 6 - The dependence of "v" on pressure at a constant bias potential of $-200 \mathrm{~V}$. $P_{N}$, Torr: $1-7 \cdot 10^{-4}, \quad 2-2 \cdot 10^{-3}$, $3-4.5 \cdot 10^{-3}$

Fig. 7 shows the dependence of the change in macrodeformation on pressure. It can be seen that there is a strong increase in the compressive strain in the pressure range (2.5-20) $10^{-4}$ Torr. At higher pressures, the magnitude of the macrodeformation of compression in the coatings remains almost unchanged.

It can be concluded that at low pressure, the main contribution to the development of macrodeformation is made by ionized particles accelerated in the field of the bias potential. At the same time, the macrodeformation level reaches $2.89 \%$ (Fig. 7).

At high pressure, when the energy of the deposited particles drops sharply due to collisions in the gap between the cathode and the substrate, there is a small macrostrain change.

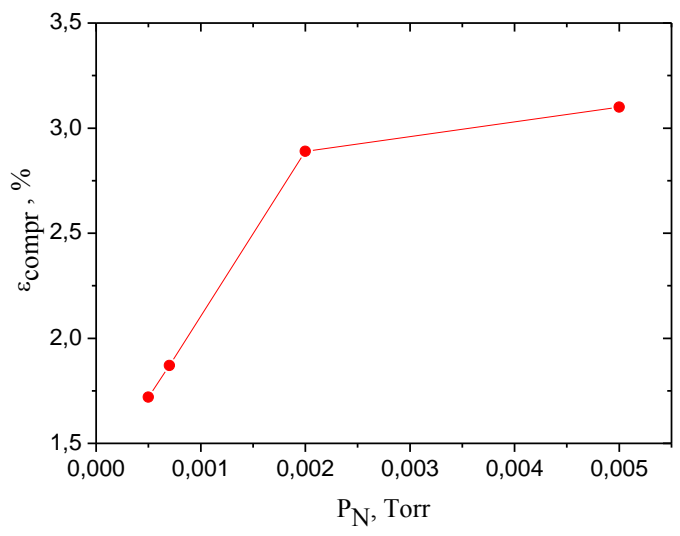

Fig. 7 - Dependence of macrodeformation change in coatings on nitrogen pressure during condensation

The most universal characteristic of the mechanical properties of coatings is their microhardness. Measurement of the microhardness of the coatings showed (Fig. 8) that the highest hardness is achieved at a pressure of $2 \cdot 10^{-3}$ Torr. In the coatings obtained at this pressure, on the one hand, a sufficiently high stress-strain state of compression takes place (Fig. 7), and on the other hand, the ratio between metal and nitrogen atoms is close to equiatomic (Table 2).

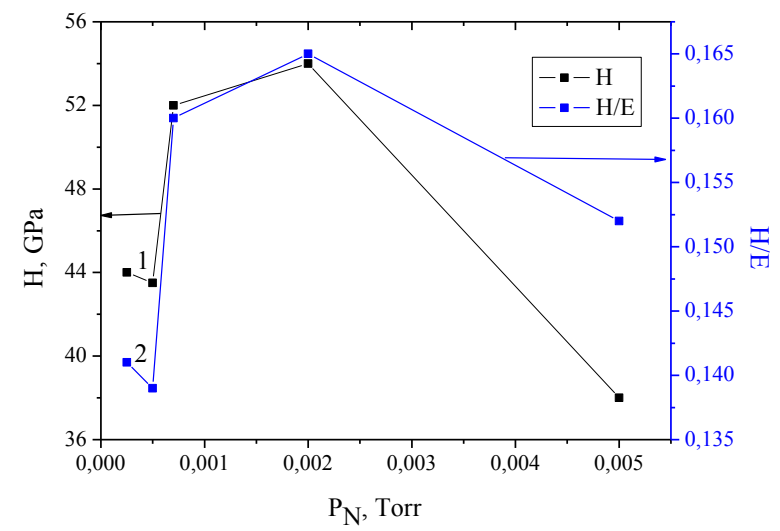

Fig. 8 - Dependence of microhardness (1) and the microhardness to modulus of elasticity ratio (2) on the nitrogen pressure during condensation

As can be seen from Fig. 8, the highest hardness is $53 \mathrm{GPa}$ and the highest ratio $H / E=0.165$ is reached at the value of $P_{N}=2 \cdot 10^{-3}$ Torr. As is well known, the value of $\mathrm{H} / \mathrm{E}$ characterizes the ability of a material to resist a change in size and shape during deformation [20]. Thus, with the highest hardness of the coating, they are characterized by the greatest resistance to the deformation process.

Fig. 9 shows the results of resistance tests. It is seen that the presence of a nanograined and practically non-textured structure at low pressure during deposition (Fig. 4) determines the increased resistance of such coatings to abrasive wear. 


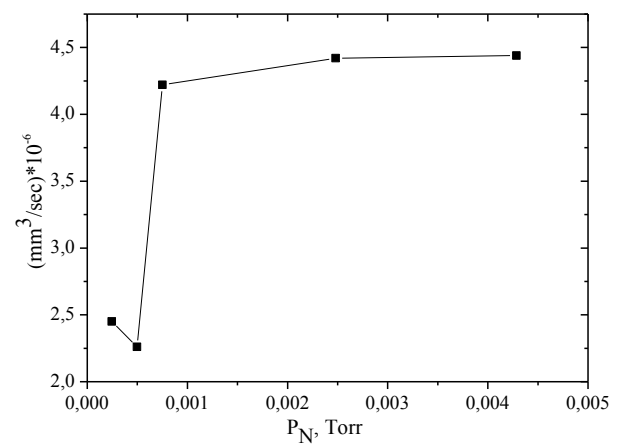

Fig. 9-Dependence of the abrasive wear of the coatings Ti-V-Zr-Nb-Hf-Ta-N on the nitrogen pressure in the vacuum chamber during the deposition process

Comparison of test results with the dependence of microstrain in crystallites (Fig. 5, dependence 2) shows a direct relationship between the deformed state and abrasive wear: a high level of microstrain of the coating crystallites determines the least abrasive wear. At the same time, the presence of high microstrain is a characteristic feature of multicomponent HEA at low deposition pressure (Fig. 5). This is due to the high efficiency of the radiation factor of defect formation (due to the low energy loss of a collision in the gap "evaporating cathode - coating" at low pressure). Also, at low pressure, the possibility of attaining a higher level of microstrain is facilitated by the incomplete filling of octahedral interstices with atoms. In such a state (i.e., the material is in a state that is pre-stoichiometric in

\section{REFERENCES}

1. M. Bourebia, L. Laouar, H. Hamadache, S. Dominiakn, Surf. Eng. 33 No 4, 255 (2017).

2. M. Kindrachuk, A. Shevchenko, A. Kryzhanovskyi, Aviation 20 No 4, 155 (2016).

3. W. Luo, X. Chen, Y. Xia, M. Chen, L. Wang, Q. Wang, W. Li, J. Yang, Adv. Energy Mater. 7 No 24, 1701083 (2017).

4. P. Kumar, A. Patnaik, S. Chaudhary, Int. J. Adhes. Adhesives 77, 1 (2017).

5. V.I. Ivashchenko, S.N. Dub, P.L. Scrynskii, A.D. Pogrebnjak, O.V. Sobol', G.N. Tolmacheva, V.M. Rogoz, A.K. Sinel'chenko, J. Superhard Mater. 38 No 2, 103 (2016).

6. M.A. Glushchenko, E.V. Lutsenko, O.V. Sobol', A.E. Barmin, A.I. Zubkov, J. Nano- Electron. Phys. 8 No 3, 03015 (2016).

7. O.V. Sobol', A.A. Andreev, V.F.Gorban, A.A. Meylekhov, H.O. Postelnyk, V.A. Stolbovoy, J. Nano- Electron. Phys. 8 No 1, 01042 (2016).

8. J.W. Yeh, S.K. Chen, S.J. Lin, J.Y. Gan, T.S. Chin, T.T. Shun, C.H. Tsau, S.Y. Chang, Adv. Eng. Mater. 6, 299 (2004).

9. C.H. Lai, S.J. Lin, J.W. Yeh, S.Y. Chang, Surf. Coat. Technol. 201 No 6, 3275 (2006).

10. O.V. Sobol', A.A. Meilekhov, Tech. Phys. Lett. 44 No 1, 63 (2018). nitrogen), the crystal lattice is more easily deformed.

As the pressure increases, the content of nitrogen atoms in the coating increases, which is accompanied by an increase in the "metal-nitrogen" covalent bond in the lattice and leads to an ordering process. This leads to a decrease in microstrain to a value of $(0.6-0.7) \%$.

\section{CONCLUSIONS}

1. In the vacuum-arc coatings obtained by evaporation of Ti-V-Zr-Nb-Hf-Ta multi-element alloy in a nitrogen atmosphere in the pressure range $2.5 \cdot 10^{-4}$. $4.5 \cdot 10^{-3}$ Torr, a single-phase state is formed (a cubic crystal lattice, structural type $\mathrm{NaCl}$ ).

2. At a bias potential of $-200 \mathrm{~V}$, the presence of atoms in alloys with very different masses ( $\mathrm{Ti}, \mathrm{V}$ and $\mathrm{Hf}, \mathrm{Ta}$ ) leads to the formation of a biaxial texture state: $[111]+[311]$.

3. At low pressure, a structure is formed with the smallest crystallite grain size.

4. The use of a multi-element composition in a single-phase state with a simple cubic lattice makes it possible to achieve high values of microstrain (up to $1.4 \%)$ with a low deposition pressure.

5. The Poisson's ratio was determined. It is 0.25 .

6 . The highest hardness of the coatings is obtained at a pressure of $2 \cdot 10^{-3}$ Torr, when the content of nitrogen atoms in the coating is about 41 at. \%.

7. Highly resistant to abrasive wear are coatings in which: the crystallite grain size is $12-25 \mathrm{~nm}$, there is a lack of texture (or a low level of texture perfection) and also a rather high microstrain in crystallites.

11. O.N. Senkov, G.B. Wilks, J.M. Scott, D.B. Miracle, Intermetallics 11, 698 (2011).

12. S.N. Grigoriev, O.V. Sobol, V.M. Beresnev, I.V. Serdyuk, A.D. Pogrebnyak, D.A. Kolesnikov, U.S. Nemchenko, J. Frict. Wear 35 No 5, 359 (2014).

13. H. Jiang, K. Han, X. Gao, Y. Lu, Z. Cao, M.C. Gao, J.A Hawk, T. Li, Mater. Design 142, 101 (2018).

14. D.B. Miracle, O.N. Senkov, Acta Mater. 122, 448 (2017).

15. C.-Y. Cheng, Y.-C. Yang, Y.-Z. Zhong, Y.-Y. Chen, T. Hsu, J.-W. Yeh, Current Opinion Solid State Mater. Sci. 21, 299 (2017).

16. M.-H. Hsieh, M.-H. Tsai, W.-J. Shen, J.-W. Yeh, Surf. Coat. Technol. 221, 118 (2013).

17. O.N. Senkov, J.M. Scott, S.V. Senkova, D.B. Miracle, J. Alloys Compd. 509 No 20, 6043 (2011).

18. O.V. Sobol', A.A. Postelnyk, A.A. Meylekhov, A.A. Andreev, V.A. Stolbovoy, V.F. Gorban, J. Nano- Electron. Phys. 9 No 3, 03003 (2017).

19. K.L. Rutherford and I.M. Hutchings, Surf. Coat. Technol. 79, 231 (1996).

20. O.N. Grigorev, B.A. Galanov, V. A. Kotenko, S. M .Ivanov, A. V. Koroteev, N. P. Brodnikovsky, J. Eur. Ceramic Soc. 30 No 11, 2173 (2010). 


\section{Структурна інженерія і механічні властивості (Ti-V-Zr-Nb-Hf-Ta)N покриттів отриманих при різному тиску}

О.В. Соболь ${ }^{1}$, А.О. Андреєв ${ }^{2}$, Г.О. Постельник ${ }^{1}$, А.О. Мейлехов ${ }^{1}$, Ю.Є. Сагаїдашніков ${ }^{1}$, В.О. Столбовий ${ }^{2}$, Н.С. Свтушенко ${ }^{1}$, Т.О. Сиренко ${ }^{3}$, Ж.В. Краевська ${ }^{1}$, О.В. Звягольский ${ }^{1}$

${ }^{1}$ Національний технічний університет "Харківський політехнічний інститут», вул. Кирпичова, 2, 61002 Харків, Украӥна

${ }^{2}$ Національний науковий иентр Харківський фбізико-технічний інститут, вул. Акаделічна, 1, Харків, 61108 Україна

${ }_{3}^{3}$ Харківський машинобудівний коледж, вул. Плеханівська 79, 61068 Харків, Украйна

В роботі досліджено вплив тиску реакційного газу на текстуру, структурно-напружений стан і механічні властивості (твердість і стійкість до абразивного зносу) в вакуумно-дугових покриттях на основі нітридів Ti-V-Zr-Nb-Hf-Tа високоентропійних сплавів. Встановлено, що при потенціалі зсуву - 200 В збільшення тиску азоту при осадженні від $2.5 \cdot 10^{-4}$ до $4.5 \cdot 10^{-3}$ Торр призводить до підвищення вмісту атомів азоту в покритті, а також формуванню бітекстурного стану: [111] + [311]. Формування біаксіальної текстури відбуваеться через наявність в сплавах атомів з масами, що сильно відрізняються (Ti, V та Hf, Ta). Використання багатоелементного складу при однофазному стані з простою кубічною решіткою дозволяе досягати високих значень мікродеформації (до 1.4 \%) при низькому тиску осадження. Встановлено, що зі збільшенням тиску азоту при осадженні призводить до збільшення макродеформації. Найбільша твердість становить 53 ГПа і досягається в покриттях, отриманих при тиску $2 \cdot 10^{-3}$ Tорр. Визначено, що високу стійкість до абразивного зносу мають покриття у яких: розмір зерен-кристалітів 12-25 нм, немає (або низький рівень досконалості) текстури, а також досить висока мікродеформація в кристалітах.

Ключові слова: Високоентропійні сплави, Тиск азоту, Покриття, Текстура, Субструктурні характеристики, Потенціал зсуву, Твердість, Абразивний знос. 